P OWER I N MOTIO N 
This page intentionally left blank 


\section{P O W E R I N M O T I O N}

Capital Mobility and the Indonesian State JEFFREY A. WINTERS

CORNELL UNIVERSITY PRESS

ITHACA AND LONDON 


\section{Copyright $\odot 1996$ by Cornell University}

All rights reserved. Except for brief quotations in a review, this book, or parts thereof, must not be reproduced in any form without permission in writing from the publisher. For information, address Cornell University Press, Sage House, 512 East State Street, Ithaca, New York 14850.

First published 1996 by Cornell University Press

Printed in the United States of America

Library of Congress Cataloging-in-Publication Data

Winters, Jeffrey A. (Jeffrey Alan), 1960-

Power in motion / Jeffrey A. Winters. p. $\mathrm{cm}$.

Includes bibliographical references and index.

ISBN 0-8014-2925-0 (cloth : alk. paper)

1. Capital movements-Indonesia. 2. Investments, Foreign-Indonesia.

3. Power (Social sciences) I. Title

HG5752.W56 1995

$332^{\prime} .042^{\prime} 09598-\mathrm{dc} 20$

Cornell University Press strives to use environmentally responsible suppliers and materials to the fullest extent possible in the publishing of its books. Such materials include vegetable-based, low-VOC inks and acid-free papers that are recycled, totally chlorine-free, or partly composed of nonwood fibers.

$\begin{array}{llllllllll}\text { Cloth printing } & 10 & 9 & 8 & 7 & 6 & 5 & 4 & 3 & 2\end{array}$ 
FOR ANNETTE M. WINTERS 
This page intentionally left blank 